\title{
Removal of Enteric Pathogens from Real Wastewater Using Single and Catalytic Ozonation
}

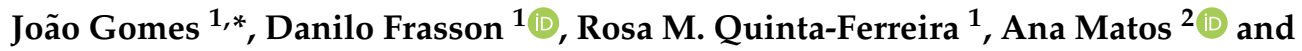 \\ Rui C. Martins ${ }^{1}$ (D) \\ 1 CIEPQPF-Chemical Engineering Processes and Forest Products Research Center, Department of Chemical \\ Engineering, Faculty of Sciences and Technology, University of Coimbra, Rua Sílvio Lima, 3030-790 Coimbra, \\ Portugal; danilobr_mf@hotmail.com (D.F.); rosaqf@eq.uc.pt (R.M.Q.-F.); martins@eq.uc.pt (R.C.M.) \\ 2 CIEPQPF-Chemical Engineering Processes and Forest Products Research Center, Faculty of Farmacy, \\ University of Coimbra, Polo das Ciências da Saúde, Azinhaga de Santa Comba, 3000-548 Coimbra, Portugal; \\ anamatos@ff.uc.pt \\ * Correspondence: jgomes@eq.uc.pt; Tel.: +351-239798722
}

Received: 24 December 2018; Accepted: 8 January 2019; Published: 12 January 2019

check for updates

\begin{abstract}
Water scarcity is one of the main problems of this century. Water reclamation appears as an alternative due to the reuse of treated wastewater. Therefore, effluents treatment technologies (activated sludge, rotary biological discs, percolating beds) must be improved since they are not able to remove emerging contaminants such as enteric pathogens (bacteria and virus). These pollutants are difficult to remove from the wastewater and lead to adverse consequences to human health. Advanced oxidation processes, such as single and catalytic ozonation, appear as suitable complements to conventional processes. Catalytic ozonation was carried out using a low-cost material, a volcanic rock. Single and catalytic ozonation were capable of promoting total Escherichia coli removal from municipal wastewater after $90 \mathrm{~min}$ of contact. The presence of volcanic rock increases disinfection efficiency since E. coli regrowth was not observed. The identified viruses (Norovirus genotype I and II and $J C$ virus) were completely removed using catalytic ozonation, whereas single ozonation was not able to eliminate $J C$ virus even after 150 min of treatment. The higher performance of the catalytic process can be explained by the formation of hydroxyl radicals, proving that disinfection occurs in the liquid bulk and not due to adsorption at the volcanic rock.
\end{abstract}

Keywords: JC virus; Norovirus; Catalytic ozonation; Volcanic rock; E. coli; Wastewater disinfection

\section{Introduction}

The conventional wastewater treatment reveals difficulty in removing both chemical and biological emerging contaminants from water [1-7]. Among these pollutants, pharmaceutical and personal care products, as well as enteric pathogens [8-12], are of concern.

The traditional municipal wastewater treatment processes are usually based on biological technologies. These encompass microorganisms' usage for wastewater treatment. However, in these plants, enteric pathogens find the desirable conditions to proliferate and can be a source of water-borne disease epidemics [13]. Pathogens comprise three main groups that can be identified as a potential threat to human health: viruses, bacteria, and protozoa [14]. Some of them are used to monitor and evaluate the quality of wastewater and drinking water such as the bacteria Escherichia coli [14]. E. coli is the most common bacteria used as an indicator of faecal contamination. Moreover, some human enteric viruses can also be used for wastewater quality testing [13]. Different serotypes of E. coli can be found in water with different consequences on human health. The most problematic is the enterohemorrhagic E. coli, so-called O157-H7, that can cause bloody diarrhea and abdominal cramps, 
as well as scarcer hemolytic uremic syndrome, which is life-threatening [15]. The enteric viruses are listed as emerging biological contaminants on the United States Environmental Protection Agency Contaminant Candidate List [16]. Nevertheless, the enteric viruses are widely present on discharged treated municipal wastewater $[17,18]$. Even so, there is still no regulation to enforce the monitoring of their concentration in treated wastewater discharges $[8,9,13]$. The main viruses found in these streams include human norovirus, polyomavirus, and Hepatitis A and E viruses. These pathogens, when in contact with individuals via the fecal-oral route or by food and environmental contamination, can cause multiple infections such as gastroenteritis and conjunctivitis, along with respiratory and liver problems [13]. Taking this into consideration, the presence of these pathogens in the natural sources can constitute an environmental and human health concern. Thus, the precautionary principle dictates that their effective removal from treated wastewater should be ensured before their discharge into natural courses. Due to the inefficiency of the traditional processes, complementary disinfection methodologies must be applied to promote the complete abatement of these pathogens $[19,20]$.

Chlorine and chlorine dioxide are the most widely used disinfection methodologies. However, these processes can lead to harmful by-products, such halogenated organic compounds, that may bring adverse health effects [21]. Another methodology typically used is ozonation, which presents the strongest disinfection capacity while avoiding toxic by-products $[20,21]$.

Ozone is a powerful oxidant capable of degrading emerging chemical contaminants [11,22,23]. This oxidant is widely used for drinking water and wastewater disinfection [20,24]. Its oxidizing capacity is proven to be efficient for bacteria, viruses, and protozoan pathogen destruction $[25,26]$. With respect to bacteria, ozone destroys the cell wall due to the protoplasmic oxidation, resulting in the cell lysis and leakage of cellular organelles [25,27]. The disinfection can occur via a direct attack of the molecular ozone or indirectly through hydroxyl radicals resulting from ozone decomposition $[20,26]$. Hydroxyl radical's production can be enhanced using heterogeneous catalysts due to the decomposition of ozone in the active sites [22,28]. The limiting step in the heterogeneous catalysis may be the catalyst material cost. However, this can be minimized using low-cost materials such as volcanic rock [29]. Gomes et al. [29] proved that the catalytic ozonation through volcanic rock is efficient for parabens decontamination.

Studies can be found in the literature with good results on pathogens disinfection with low ozone dosages and short contact periods [25]. Ozone was very quick at removing E. coli from ultrapure water using $0.16 \mathrm{mg} \mathrm{O}_{3} / \mathrm{L}$ of transferred ozone dose (TOD) without regrowth [26]. Regarding studies involving viruses, Shin and Sobsey [30] verified a reduction of about $3 \log$ of the Norwalk virus after $10 \mathrm{~s}$ of ozone contact time. Moreover, Schaar et al. [31] verified a reduction of 4-5 log for bacteriophage MS2 (model virus) spiked in tertiary effluent in an ozonation pilot plant using 5 to $7 \mathrm{mg} / \mathrm{L}$ of ozone dosage. The presence of substances in the real wastewater, such as bromide and iodide, reduced the MS2 removal and inactivation. However, removal can be completed by increasing ozone dose [32].

The aim of this work is attesting the capacity of single and catalytic ozonation (using a low-cost material as a catalyst) to remove bacteria and viruses from a secondary municipal wastewater. Since the effluent contained a significant amount of human JC polyomavirus, as well as genotypes I and II of human norovirus, these were the target viruses evaluated. Moreover, E. coli was selected as the target bacteria. To the best of our knowledge, this is the first work dealing with virus and bacteria removal from real municipal wastewater through catalytic ozonation using low-cost catalysts.

\section{Materials and Methods}

\subsection{Chemicals and Volcanic Rock}

Lauryl sulphate agar, tryptic soy agar, buffered peptone water, Bactident ${ }^{\circledR}$ Oxidase, and Bactident ${ }^{\circledR}$ KOVACS Indol reagent purchased from Merck KGaA (Darmstadt, Germany) were used for identification and quantification of E. coli. Real-time PCR protocols were used for studying viruses. All samples were processed in order to concentrate viral particles and were submitted 
to nucleic acid extraction using a QIAmp ${ }^{\circledR}$ Viral RNA Mini Kit purchased from QIAGEN ${ }^{\circledR}($ VWR, Lisbon, Portugal). According to the virus type, different reagents were used in the amplification and quantification steps, such as Maxima Probe qPCR Master Mix (2X) from Thermo Fisher Scientific (Lisbon, Portugal), SuperscriptTM III RT/Platinum Reaction Mix (2X), Enzyme Mix and Taq enzyme purchase from Invitrogen ${ }^{\circledR}$, and specific primers and probes acquired from Thermo Fisher Scientific (Lisbon, Portugal).

The catalyst used in this study was a volcanic rock collected from São Miguel (Azores Islands, Portugal). This is an abundant natural material resulting from a volcanic magma eruption. It presents a high porosity and metal richness. The main characterization of the catalyst was previously carried out by Gomes et al. [29]. Briefly, the pHpzc (point zero charge) was 5.7, the BET surface area was $28.3 \mathrm{~m}^{2} / \mathrm{g}$, and the presence of two minerals of augite and diopside was detected through XRD. These minerals were characterized by a high percentage of silica. Moreover, the presence of $\mathrm{Fe}$ and $\mathrm{Al}$ was confirmed using Scanning Electron Microscopy- Energy Dispersive X-Ray analysis (SEM-EDS) a TESCAN VEGA 3 SBH - Easy Probe equipped- Bruker Nano XFlash®detector (Brno, Czech Republic) [29].

\subsection{Experimental Procedures for Single and Catalytic Ozonation}

Single and catalytic ozonation were carried out in a $2 \mathrm{~L}$ glass reactor with a thermostatic water-bath to maintain the temperature $\left(25 \pm 1^{\circ} \mathrm{C}\right)$ and continuous stirring using a magnetic stirrer at $700 \mathrm{rpm}[33,34]$. Moreover, when a solid catalyst was used, the size of particles used was lower than $105 \mu \mathrm{m}$. Under these conditions, the chemical regime was guaranteed [28].

The reactor was covered with aluminum foil to inhibit the interference of visible and sunlight radiation since it can affect disinfection [35]. Ozone was produced from pure oxygen (99.9\%, Praxair) using an ozone generator (802 N, BMT). The inlet and outlet concentrations of this oxidant were measured using gas ozone analyzers (BMT 963 vent and BMT 964 vent, respectively). With the values measured by the gas ozone analyzers, transferred ozone dose (TOD), expressed in $\mathrm{mgO}_{3} / \mathrm{L}$, could be determined using Equation (1), where the volume of effluent $(2 \mathrm{~L})$ used in the reactor is represented by $V_{\text {liquid }}, Q_{\text {Gas }}$ is the gas flow rate $(0.2 \mathrm{~L} / \mathrm{min})$, and $\left[\mathrm{O}_{3}\right]^{\text {in }}$ and $\left[\mathrm{O}_{3}\right]^{\text {out }}$ are the inlet and outlet ozone concentrations in the reactor, respectively [23].

$$
T O D=\int_{0}^{t} \frac{Q_{\text {Gas }}}{V_{\text {liquid }}} \times\left(\left[\mathrm{O}_{3}\right]^{\text {in }}-\left[\mathrm{O}_{3}\right]^{\text {out }}\right) \times d t
$$

As for the catalytic experiments, the catalyst load was $0.5 \mathrm{~g} / \mathrm{L}$. These conditions were selected based on the good performance obtained in a previous work related with parabens degradation [29]. Moreover, the catalyst was previously stirred with the effluent before feeding the ozonated gas to guarantee the particles suspension. Samples were withdrawn and rapidly filtered using a $0.45 \mu \mathrm{m}$ filter in order to remove the catalyst.

Samples for bacteriological analysis were processed immediately after collection. As for the samples aimed for virological studies, they were filtered using a $0.2 \mu \mathrm{m}$ filter to remove bacteria and suspended soils, and the filtrated samples were stored at $-20^{\circ} \mathrm{C}$ until analysis.

\subsection{Municipal Wastewater Sampling}

The municipal effluent provided from the secondary settler of a Portuguese wastewater treatment plant was used. Briefly, in that plant, the wastewater first suffers a pre-treatment (grading and iron chloride addition) and primary settling. Then, the wastewater is directed to a trickling bed biological reactor to remove most of the organic matter. A secondary settler is then used before the wastewater is discharged. Samples used were collected just before the discharge and used within $24 \mathrm{~h}$. 


\subsection{Quantification of Culturable Bacteria-E. coli}

E. coli quantification was carried out following the membrane filtration method (ISO 9308-1). Each sample underwent serial decimal dilutions (from $10^{-1}$ to $10^{-4}$ ), which were filtered using a $0.45 \mu \mathrm{m}$ cellulose membrane, in duplicate. Each membrane was inoculated in lauryl sulphate agar, and incubated for $24 \pm 2 \mathrm{~h}$ at $37 \pm 0.2^{\circ} \mathrm{C}$. After incubation, yellow colonies developed within the membrane comprising E. coli and other coliforms bacteria, which were counted and reported as colony forming units (CFU) per mL. To estimate how many of the counted yellow colonies corresponded to E. coli, confirmation tests were done. For such a purpose, five colonies of each considered plate (performing 10 colonies for each analyzed sample) were selected for inoculation in tryptic soy agar and incubated for $24 \mathrm{~h}$ at $37^{\circ} \mathrm{C}$. An oxidase test was performed for each obtained culture, and all oxidase-negative bacteria were further inoculated in buffered peptone water, and incubated at $44{ }^{\circ} \mathrm{C}$ for $24 \mathrm{~h}$ for an indol test. All selected yellow colonies in lauril-sulfate agar, with an oxidase-negative test and indol-positive results were considered as E. coli, and extrapolation for all counted yellow colonies were performed considering the proportion of E. coli confirmed colonies in the 10 selected ones.

\subsection{Regrowth}

When the E. coli quantification results are negative, it is important to guarantee that bacteria were really removed, so a regrowth test is executed. For such purpose, the sample was incubated at $37^{\circ} \mathrm{C}$ for $24 \mathrm{~h}$ before being processed as described before (Section 2.4). If the following result is negative, it can be considered that $E$. coli was effectively removed.

\subsection{Viruses Analysis}

The virus studies were performed through real-time polymerase chain reaction (PCR) protocols, with virus identification and quantification being performed with a basis in their specific genome nucleotide sequence. Apart from the existent viruses in the samples, Mengo virus was spiked in collected samples in order to evaluate the viral recovery efficiency. Viral particles present in each sample were concentrated through an ultracentrifugation protocol [36]. Briefly, $75 \mathrm{~mL}$ of the sample, spiked with $0.5 \mathrm{~mL}$ of Mengo virus, were submitted to an ultracentrifugation (152,783 RCF/g) for $90 \mathrm{~min}$ at $18{ }^{\circ} \mathrm{C}$ for pellet formation. The supernatant was removed, and the pellet was resuspended in $0.5 \mathrm{~mL}$ of supernatant. Chloroform $(0.5 \mathrm{~mL})$ was added, and after convenient homogenization, centrifugation (405 RCF/g for $10 \mathrm{~min}$ ) was carried out for phase separation (aqueous and organic phases), with selection of the liquid phase for analysis.

The liquid phase $(0.140 \mathrm{~mL})$ was submitted to nucleic acids extraction through the commercially available kit QIAmp ${ }^{\circledR}$ Viral RNA Mini Kit $\left(\right.$ QIAGEN $^{\circledR}$, Izasa, Carnaxide, Portugal) according to the manufacturer's instructions. The viral genome was eluted in $60 \mu \mathrm{L}$ of elution buffer and stored at $-20^{\circ} \mathrm{C}$ until further analysis.

Amplification reactions were carried out in a final volume of $25 \mu \mathrm{L}$ containing $7.5 \mu \mathrm{L}$ of the viral genome. Primers and probes used for detection and quantification of the different virus were in accordance with literature [37-43].

For JC polyomavirus detection and quantification, $17.5 \mu \mathrm{L}$ of Maxima Probe qPCR Master Mix (2X) (Thermo Fisher Scientific, Lisbon, Portugal), containing $300 \mathrm{nM}$ of each primer, and $200 \mathrm{nM}$ of TaqMan probe were used. The thermal cycling protocol included an initial 2 min incubation at $50{ }^{\circ} \mathrm{C}$, followed by $10 \mathrm{~min}$ at $95^{\circ} \mathrm{C}$, and 45 cycles of $95^{\circ} \mathrm{C}$ for $15 \mathrm{~s}$, and $60^{\circ} \mathrm{C}$ for $60 \mathrm{~s}$.

Regarding noroviruses, both genotypes I and II, and hepatitis A virus, amplification was conducted in a master mix containing $12.5 \mu \mathrm{L}$ of SuperScript III RT reaction mix (Invitrogen ${ }^{\circledR}$ ), $0.5 \mu \mathrm{L}$ of SuperScript III RT/Taq Mix (Invitrogen ${ }^{\circledR}$ ), $500 \mathrm{nM}$ of forward primer, $900 \mathrm{nM}$ of reverse primer, and $250 \mathrm{~nm}$ of TaqMan probe. The thermal cycling protocol included an initial $1 \mathrm{~h}$ incubation at $55^{\circ} \mathrm{C}$ for reverse transcription, followed by $5 \mathrm{~min}$ at $95^{\circ} \mathrm{C}$, and 45 cycles of $95^{\circ} \mathrm{C}$ for $15 \mathrm{~s}, 60^{\circ} \mathrm{C}$ for $60 \mathrm{~s}$, and $65^{\circ} \mathrm{C}$ for $60 \mathrm{~s}$. 
For hepatitis E virus (HEV) detection, the amplification reaction was carried out in a total volume of $25 \mu \mathrm{L}$, containing $400 \mathrm{nM}$ of each primer, $120 \mathrm{nM}$ of HEV probe, and $0.8 \mu \mathrm{L}$ of Superscript ${ }^{\mathrm{TM}} \mathrm{III}$ RT/Platinum ${ }^{\circledR}$ Taq enzyme (Invitrogen ${ }^{\circledR}$, Alfagene, Portugal). RT-PCR was carried out on the BIORAD CFX96 $6^{\circledR}$ under the following temperature conditions: $50^{\circ} \mathrm{C}$ for $30 \mathrm{~min}, 95^{\circ} \mathrm{C}$ for $2 \mathrm{~min}$, and 45 cycles of $95{ }^{\circ} \mathrm{C}$ for $15 \mathrm{~s}$, and $60^{\circ} \mathrm{C}$ for $1 \mathrm{~min}$. Negative and positive controls were used for each set of amplification reactions.

The construction of the standard curves for the viral load quantification was based on serial decimal dilutions of plasmids containing viral genome amplified regions, within the range of $1-10^{5}$ genome copies per PCR reaction. The virus concentration expressed as $\log _{10}$ genome copies per $\mathrm{L}$ of wastewater $\left(\log _{10} \mathrm{GC} / \mathrm{L}\right)$ was calculated based on the cycle threshold $(\mathrm{Ct})$ values and the standard curves.

\section{Results}

\subsection{E. coli Removal from Municipal Wastewater}

Both ozonation processes, single and catalytic, were carried out for $150 \mathrm{~min}$ aiming toward the disinfection of secondary municipal effluent. Samples were withdrawn at the start of the experiments and at different time intervals, such as 30,60, 90, 120, and $150 \mathrm{~min}$. Then, the quantification and confirmation tests of culturable bacteria were carried out.

E. coli removal was expressed as a function of TOD values since in this kind of process, the limiting step is ozone production. Therefore, the TOD was analyzed to make conclusions about the economic viability of processes. Moreover, the amount of ozone required is a more reliable way to compare different ozone-based processes [44]. Table 1 reveals that the TOD was slightly lower when the catalyst was used. This means that the catalytic ozonation needed a lower amount of ozone than single ozonation for the disinfection. The TOD values required to achieve total E. coli removal were much higher for the actual wastewater compared to the results achieved when ultrapure water spiked with $3 \log$ of E. coli was used. In that previous case, the maximum value of $0.16 \mathrm{mgO}_{3} / \mathrm{L}$ corresponding to $30 \mathrm{~s}$ of treatment was required to achieve total E. coli depletion [26]. The presence of real wastewater and its constituents such as organic matter and ionic species affects significantly the disinfection treatment $[20,25,32]$, which will entail a higher ozone dose required for an effective disinfection.

Table 1. TOD value through each treatment (single and catalytic ozonation).

\begin{tabular}{ccc}
\hline & Ozonation & Catalytic Ozonation \\
\hline Time $(\mathbf{m i n})$ & TOD $\left(\mathbf{m g O}_{3} / \mathbf{L}\right)$ & TOD $\left(\mathbf{m g O}_{3} / \mathbf{L}\right)$ \\
\hline 0 & 0.00 & 0.00 \\
30 & 14.4 & 12.3 \\
60 & 25.0 & 21.3 \\
90 & 34.8 & 29.9 \\
120 & 44.7 & 39.0 \\
150 & 54.7 & 48.5 \\
\hline
\end{tabular}

The initial E. coli concentration determined to be in the secondary municipal wastewater was of about $4 \log$ which is not significantly different from the load tested with the spiked ultrapure water [26]. The resulting E. coli concentration using both processes as a function of TOD is shown in Figure 1.

As can be seen in Figure 1, both treatments were able to remove all E. coli. In the first $30 \mathrm{~min}$, almost $2 \operatorname{logs}$ of $E$. coli were removed, which proved the oxidative capacity of ozone. Total E. coli removal was achieved after $90 \mathrm{~min}$, which corresponds to a TOD value of $29.9 \mathrm{mgO}_{3} / \mathrm{L}$ for catalytic ozonation and $34.8 \mathrm{mgO}_{3} / \mathrm{L}$ for single ozonation. Therefore, the presence of a catalyst allows a reduction of TOD required, maybe due to the formation of hydroxyl radicals, which increases the disinfection rate. In a previous work, the hydroxyl radical activity was checked with the same catalyst for parabens 
mixture detoxification [29] through the usage of a radical scavenger (Isopropanol). The results obtained shown that a hydroxyl radical seems to be the predominant species for parabens degradation with catalytic ozonation with this very same catalyst. Thus, probably hydroxyl radicals are the main species responsible for the disinfection enhancement observed. Moreover, after $120 \mathrm{~min}$, almost all coliforms bacteria were removed using catalytic ozonation, whereas single ozonation only reached these results after $150 \mathrm{~min}$ of oxidation corresponding a TOD value of $54.7 \mathrm{mgO}_{3} / \mathrm{L}$.

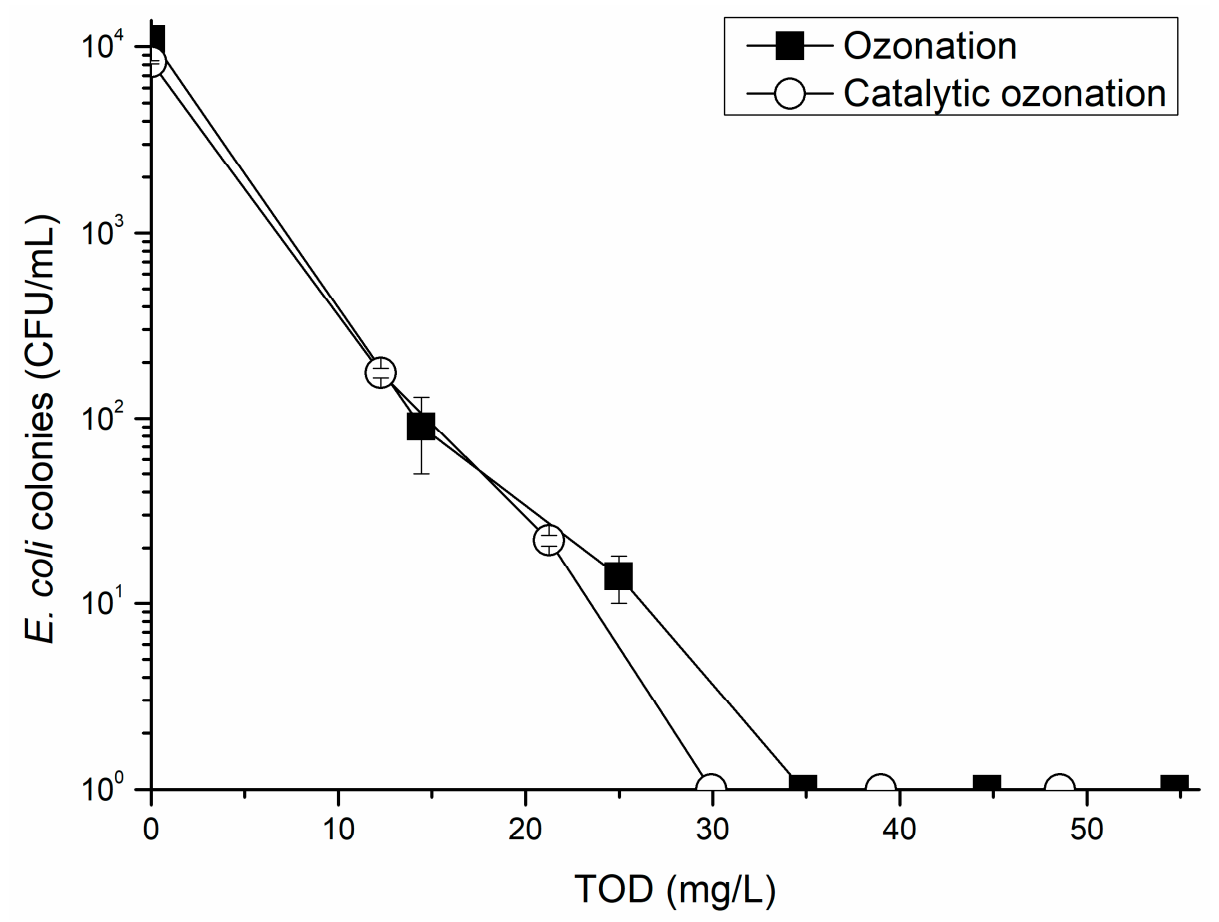

Figure 1. E. coli concentration using single and catalytic ozonation as function of TOD (using $\log _{10}$ scale).

The samples collected at 90, 120, and $150 \mathrm{~min}$ from the catalytic process were submitted to regrowth analyses. Bacteria regrowth was observed, but mostly as pink colonies, which are not characteristic of E. coli. However, for the single process, the samples collected at those very same reaction times presented pink and yellow colonies, which means coliforms and E. coli regrowth occurred. The number of regrown yellow colonies decreased between the 90 and 150 min samples. These results attest the efficiency of the catalytic ozonation regarding the complete removal of E. coli. Despite this, the catalytic ozonation result was not different from the single ozonation, since the dissolved molecular ozone had an important role on the E. coli inactivation $[45,46]$.

In order to understand if some $E$. coli can be removed through adsorption onto the catalyst surface during the catalytic process, the wastewater was continuously stirred with the volcanic rock using the same solid load that was used during catalytic ozonation. During the process, oxygen was bubbled into the reactor instead of the ozonated gas mixture. The procedure was carried out for $150 \mathrm{~min}$. Samples were taken at the start without any catalyst or oxygen, 20 min after stirring the effluent with the catalyst without oxygen, and $150 \mathrm{~min}$ after the feeding the oxygen to effluent/catalyst. Figure 2 shows the E. coli concentration as a function of time.

It is noted that the catalyst itself is not able to remove E. coli. In this experiment, the quantity of bacteria increased during the initial 20 min of stirring with the catalyst and without $\mathrm{O}_{2}$. Over the next $150 \mathrm{~min}$ there was no significant variation in bacterial concentration. This increasing quantity of bacteria may be related to the effluent temperature in the reactor $\left(25 \pm 1^{\circ} \mathrm{C}\right)$, which is favorable for bacteria growth. Thus, these results confirm that it is the combination of ozone and the catalyst that makes the treatment effective. As no adsorption was verified on the catalyst surface, it can be concluded that the disinfection occurs on the liquid bulk and not on the volcanic rock surface. 


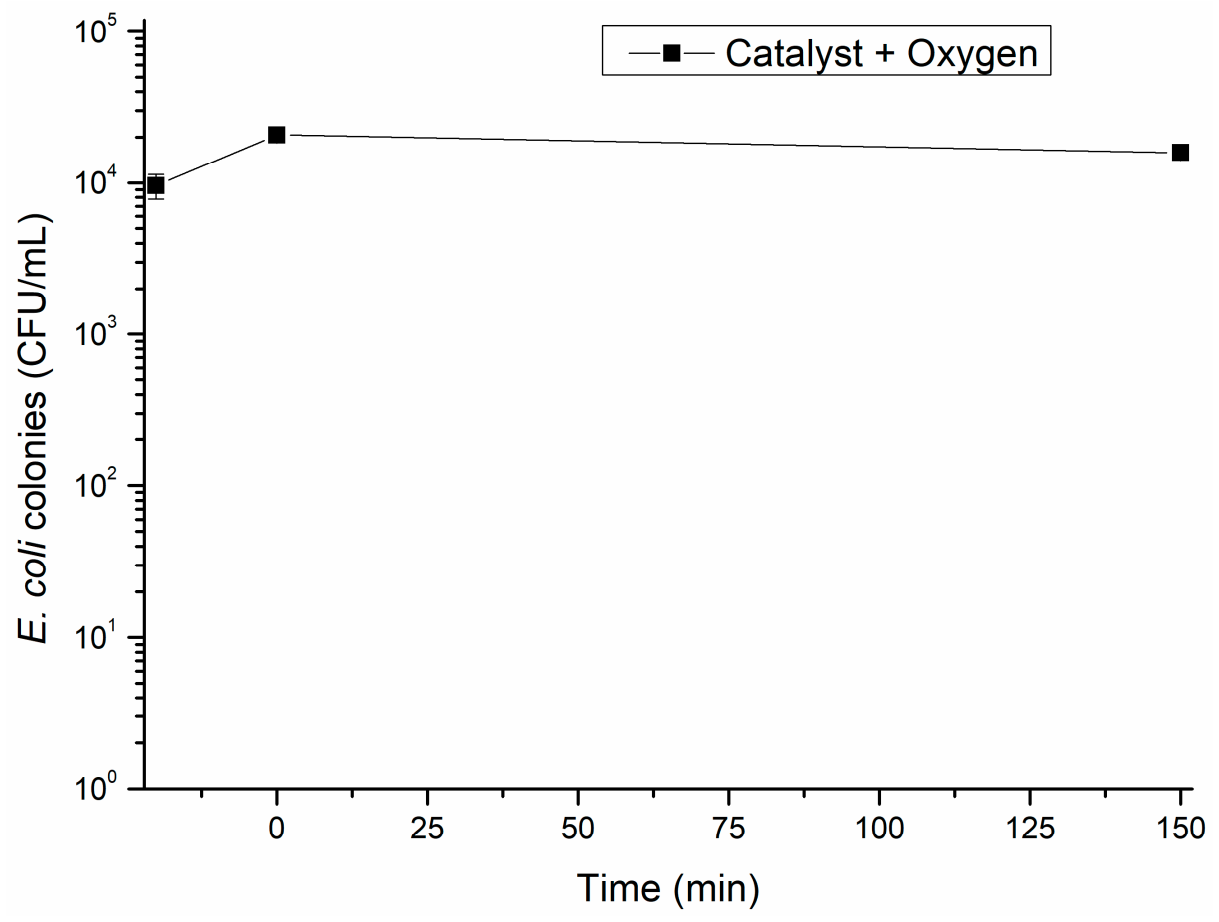

Figure 2. E. coli concentration using wastewater and volcanic rock as a function of time $(-20$ to $0 \mathrm{~min}$ without oxygen and from 0 min bubbling $\mathrm{O}_{2}$, using $\log _{10}$ scale).

\subsection{Virus Removal from Municipal Effluent}

The initial and final samples collected from each treatment, were submitted to different PCR protocols in order to identify and quantify some viruses.

Different viruses were identified in the effluent, such as JC polyomavirus and Norovirus genotype I and II, with high initial concentrations ranging from 3000 to 945,000 copies per liter. Hepatitis A and $\mathrm{E}$ viruses were not detected in the effluent sample analyzed. Figure 3 summarizes the results of the amount of each virus in the initial wastewater and after $150 \mathrm{~min}$ of single and catalytic ozonation processes, as well as after 150 min of bubbling the effluent with oxygen and volcanic rock.

Among the identified viruses, the virus with the highest initial concentration in all experiments was JC polyomavirus, a human virus with a circular dsDNA genome, widely present in urban sewages [47-49], due to its continuous excretion by infected individuals [50]. The pathogenicity and virulence of this type of virus is mostly associated with immunocompromised states, such as those observed in patients with advanced HIV infection or leukemia.

The complete removal of $J C$ polyomavirus was only achieved using the catalytic ozonation process, even if a higher initial virus concentration was detected at the beginning of the catalytic process compared with single ozonation. The lower efficiency of the treatment processes regarding this virus may be related with its higher initial concentration. Moreover, since it is a DNA virus, it should be more resistant to disinfection. In the experimental procedure using the catalyst bubbled with oxygen, only the concentration of JC polyomavirus slightly decreased. Thus, adsorption into the catalyst does not explain the efficiency of catalytic ozonation for virus removal. The combination between ozone and the volcanic rock potentiate disinfection.

The experimental results confirm the efficacy of the catalytic ozonation process when compared with the single ozone system and the catalyst itself. This positive performance can be justified once more with the assumed formation of highly reactive species when the low-cost catalyst is used in the ozonation process [29]. 


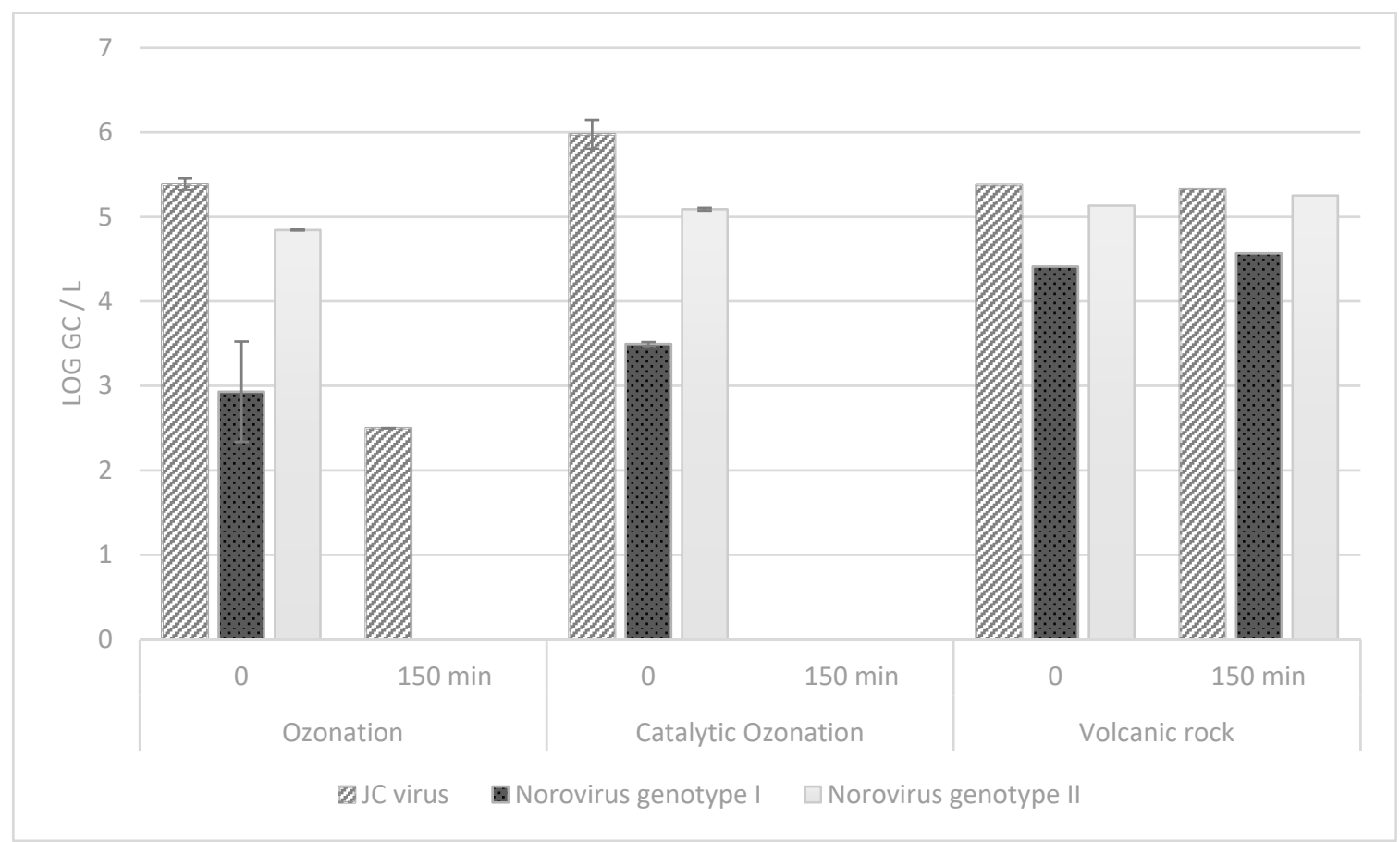

Figure 3. Initial and final virus concentration after single ozonation, catalytic ozonation, and contact with the catalyst.

\subsection{Economic Implications}

It can be observed that for the same reaction time, the transferred ozone dose was lower when the catalyst was used. This leads to economic benefits, since less ozone used implies less energy consume for ozone production and process.

The costs associated with ozone production can be estimated considering a value of $12 \mathrm{kWh} / \mathrm{kgO}_{3}$ as the base, which is the average energy consumption in the ozone production in wastewater treatment plants [51]. The virus disinfection over $150 \mathrm{~min}$ of treatment for the single ozonation process consumed $0.66 \mathrm{kWh} / \mathrm{m}^{3}$, while for the catalytic treatment, $0.58 \mathrm{kWh} / \mathrm{m}^{3}$ was required. Nevertheless, it should be reminded that JC polyomavirus was only totally depleted when catalytic ozonation was applied. Thus, it would be necessary to use more energy so that single ozonation treatment be able to totally remove JC polyomavirus. On the other hand, in the case of catalytic ozonation, it was possible to achieve the total E. coli removal using a TOD value of $29.9 \mathrm{mg} / \mathrm{L}$, which means an energetic consumption of $0.36 \mathrm{kWh} / \mathrm{m}^{3}$. It must be pointed that no regrowth was found afterwards. Contrarily, for single ozonation, total E. coli removal was achieved using a TOD value of $34.8 \mathrm{mg} / \mathrm{L}$, which represents an energy consumption of $0.42 \mathrm{kWh} / \mathrm{m}^{3}$. Moreover, for this treatment stage, E. coli regrowth was still found. For no regrowth to be detected, a higher amount of ozone was required, which represented an energetic consumption above $0.66 \mathrm{kWh} / \mathrm{m}^{3}$.

Regarding the real application of catalytic ozonation for enteric pathogens removal, it seems that the low-cost material usage and the improvement on the efficiency of the ozonation process regarding energy consume can be considered a suitable option to promote the disinfection of actual wastewater.

The volcanic rock is considered a low-cost catalyst since can be found abundantly in volcanic areas and no sophisticated preparation procedures are required such as those necessary for the preparation of traditional catalysts. While for the typical catalysts, precursors and solvents are needed-besides washing, drying and calcination steps (involving energy costs) - in this case, only a washing procedure would be needed. Of course, the environmental damage due to the rock's extraction should be considered. However, all catalysts based on metals require metal precursors that are produced using mining products as raw materials. Also, mining presents an important environmental impact. Still, 
since volcanic areas are specific and usually protected, the full-scale application of this technology will require an environmental impact assessment.

\section{Conclusions}

Single and catalytic ozonation using a low-cost volcanic rock catalyst were tested to promote the disinfection of E. coli, norovirus genotype I and II, and JC polyomavirus from a secondary municipal wastewater. Disinfection of $E$. coli was efficient for both treatments, which revealed an ozone disinfection character. Moreover, the presence of a low-cost catalyst allowed for the reduction in the TOD required for E. coli abatement compared to the single ozonation process. In fact, for single ozonation, it was possible to verify some fecal bacteria regrowth after the treatment, whereas for catalytic ozonation, E. coli regrowth was not detected. This means that the low-cost material allowed more efficient disinfection and reduced the required ozone amount. The main reason for this improvement is the formation of hydroxyl radicals during catalytic ozonation. Regarding the removal of the identified virus in the municipal wastewater, norovirus genotype I and II were removed in both conditions after $150 \mathrm{~min}$ of treatment. However, the JC polyomavirus, which is characterized by its circular dsDNA genome, was only completely removed by the catalytic ozonation process. Thus, the combination of the catalyst provided from a natural source and ozone potentiate disinfection.

Regarding the economic analysis, the presence of a catalyst allows a reduction in terms of ozone amount, which will represent a lower impact in terms of ozone production costs. Thus, the low-cost catalyst makes this an interesting process for wastewater disinfection and water reclamation.

Author Contributions: Conceptualization, J.G., A.M., and R.C.M., data curation, D.F. and A.M.; writing-original draft preparation, J.G., D.F.; writing-review and editing, A.M., R.M.Q.-F., and R.C.M.; supervision, R.M.Q.-F. and R.C.M.; project administration, R.C.M.; funding acquisition, R.C.M.

Funding: The authors gratefully acknowledge Fundação para a Ciência e Tecnologia by the financial support under IFCT2014 programme (IF/00215/2014) with financing from the European Social Fund and the Human Potential Operational Programme

Conflicts of Interest: The authors declare no conflict of interest. The funders had no role in the design of the study; in the collection, analyses, or interpretation of data; in the writing of the manuscript, or in the decision to publish the results.

\section{References}

1. Nabeel, F.; Rasheed, T.; Bilal, M.; Li, C.; Yu, C.; Iqbal, H.M.N. Bio-Inspired Supramolecular Membranes: A Pathway to Separation and Purification of Emerging Pollutants. Sep. Purif. Rev. 2018, 1-17. [CrossRef]

2. Hernandez-Vargas, G.; Sosa-Hernández, J.E.; Saldarriaga-Hernandez, S.; Villalba-Rodríguez, A.M.; Parra-Saldivar, R.; Iqbal, H.M.N. Electrochemical Biosensors: A Solution to Pollution Detection with Reference to Environmental Contaminants. Biosensors 2018, 8, 29. [CrossRef] [PubMed]

3. Rasheed, T.; Bilal, M.; Nabeel, F.; Adeel, M.; Iqbal, H.M.N. Environmentally-related contaminants of high concern: Potential sources and analytical modalities for detection, quantification, and treatment. Environ. Int. 2019, 122, 52-66. [CrossRef] [PubMed]

4. Diamond, J.; Munkittrick, K.; Kapo, K.E.; Flippin, J. A Framework for Screening Sites at Risk from Contaminants of Emerging Concern. Environ. Toxicol. Chem. 2015, 34, 2671-2681. [CrossRef] [PubMed]

5. Gomes, I.B.; Simões, L.C.; Simões, M. The effects of emerging environmental contaminants on Stenotrophomonas maltophilia isolated from drinking water in planktonic and sessile states. Sci. Total Environ. 2018, 643, 1348-1356. [CrossRef] [PubMed]

6. Rasheed, T.; Bilal, M.; Iqbal, H.M.N.; Hu, H.; Zhang, X. Reaction Mechanism and Degradation Pathway of Rhodamine 6G by Photocatalytic Treatment. Water Air Soil Pollut. 2017, 228, 291. [CrossRef]

7. Bilal, M.; Rasheed, T.; Iqbal, H.M.N.; Hu, H.; Wang, W.; Zhang, X. Toxicological Assessment and $\mathrm{UV} / \mathrm{TiO}_{2}$-Based Induced Degradation Profile of Reactive Black 5 Dye. Environ. Manag. 2018, 61, 171-180. [CrossRef] 
8. Tondera, K.; Klaer, K.; Gebhardt, J.; Wingender, J.; Koch, C.; Horstkott, M.; Strathmann, M.; Jurzik, L.; Hamza, I.A.; Pinnekamp, J. Reducing pathogens in combined sewer overflows using ozonation or UV irradiation. Int. J. Hyg. Environ. Health 2015, 218, 731-741. [CrossRef]

9. Campos, C.J.A.; Avant, J.; Lowther, J.; Till, D.; Lees, D.N. Human norovirus in untreated sewage and effluents from primary, secondary and tertiary treatment processes. Water Res. 2016, 103, 224-232. [CrossRef]

10. Molins-Delgado, D.; Díaz-Cruz, M.S.; Barceló, D. Ecological risk assessment associated to the removal of endocrine-disrupting parabens and benzophenone-4 in wastewater treatment. J. Hazard. Mater. 2016, 310, 143-151. [CrossRef]

11. Gomes, J.; Costa, R.; Quinta-Ferreira, R.; Martins, R. Application of ozonation for pharmaceuticals and personal care products removal from water. Sci. Total Environ. 2017, 586, 265-283. [CrossRef] [PubMed]

12. Wang, H.; Sikora, P.; Rutgersson, C.; Lindh, M.; Brodin, T.; Björlenius, B.; Larsson, D.G.J.; Norder, H. Differential removal of human pathogenic viruses from sewage by conventional and ozone treatments. Int. J. Hyg. Environ. Health 2018, 221, 479-488. [CrossRef] [PubMed]

13. Osuolale, O.; Okoh, A. Human enteric bacteria and viruses in five wastewater treatment plants in the Eastern Cape, South Africa. J. Infect. Public Health 2017, 10, 541-547. [CrossRef] [PubMed]

14. Jacangelo, J.G.; Trussell, R.R. International report: Water and wastewater disinfection-trends, issues and practices. Water Sci. Technol. Water Supply 2002, 2, 147-157. [CrossRef]

15. Nguyen, Y.; Sperandio, V. Enterohemorrhagic E. coli (EHEC) pathogenesis. Front. Cell. Infect. Microbiol. 2012, 2, 90. [CrossRef] [PubMed]

16. US EPA. National Primary Drinking Water Regulations I US EPA. 2018. Available online: https://www. epa.gov / ground-water-and-drinking-water/national-primary-drinking-water-regulations (accessed on 27 April 2018).

17. Okoh, A.I.; Sibanda, T.; Gusha, S.S. Inadequately treated wastewater as a source of human enteric viruses in the environment. Int. J. Environ. Res. Public Health 2010, 7, 2620-2637. [CrossRef] [PubMed]

18. Kitajima, M.; Iker, B.C.; Pepper, I.L.; Gerba, C.P. Relative abundance and treatment reduction of viruses during wastewater treatment processes-Identification of potential viral indicators. Sci. Total Environ. 2014, 488-489, 290-296. [CrossRef]

19. Gomes, J.; Matos, A.; Quinta-Ferreira, R.; Martins, R.C. Environmentally applications of invasive bivalves for water and wastewater decontamination. Sci. Total Environ. 2018, 630, 1016-1027. [CrossRef]

20. Gomes, J.; Matos, A.; Gmurek, M.; Quinta-Ferreira, R.; Martins, R.C. Ozone and Photocatalytic Processes for Pathogens Removal from Water: A Review. Catalysts 2019, 9, 46. [CrossRef]

21. Percival, S.; Yates, M.; Williams, D.; Chalmers, R.; Gray, N. Microbiology of Waterborne Diseases, 2nd ed.; Elsevier: Oxford, UK, 2014; pp. 537-615.

22. Kasprzyk-Hordern, B.; Ziólek, M.; Nawrocki, J. Catalytic ozonation and methods of enhancing molecular ozone reactions in water treatment. Appl. Catal. B Environ. 2003, 46, 639-669. [CrossRef]

23. Gomes, J.; Bednarczyk, K.; Gmurek, M.; Stelmachowski, M.; Zaleska-Medynska, A.; Bastos, F.; Quinta-Ferreira, M.; Costa, R.; Quinta-Ferreira, R.; Martins, R. Noble metal-TiO 2 supported catalysts for the catalytic ozonation of parabens mixtures. Proc. Saf. Environ. Prot. 2017, 111, 148-159. [CrossRef]

24. Demeestere, K.; Gago-Ferrero, P.; Van Langenhove, H.; Díaz-Cruz, M.; Barceló, D. Ozonation as an Advanced Treatment Technique for the Degradation of Personal Care Products in Water. Handb. Environ. Chem. 2014, 36, 375-397.

25. Lazarova, V.; Liechti, P.; Savoye, P.; Hausler, R. Ozone disinfection: Main parameters for process design in wastewater treatment and reuse. J. Water Reuse Desalin. 2013, 3, 337. [CrossRef]

26. Gomes, J.F.; Lopes, A.; Gonçalves, D.; Luxo, C.; Gmurek, M.; Costa, R.; Quinta-Ferreira, R.M.; Martins, R.C.; Matos, A. Biofiltration using C. fluminea for E.coli removal from water: Comparison with ozonation and photocatalytic oxidation. Chemosphere 2018, 208, 674-681. [CrossRef] [PubMed]

27. Sousa, J.M.; Macedo, G.; Pedrosa, M.; Becerra-Castro, C.; Castro-Silva, S.; Pereira, M.F.R.; Silva, A.M.T.; Nunes, O.C.; Manaia, C.M. Ozonation and UV254 nm radiation for the removal of microorganisms and antibiotic resistance genes from urban wastewater. J. Hazard. Mater. 2017, 323, 434-441. [CrossRef] [PubMed]

28. Martins, R.C.; Quinta-Ferreira, R.M. Catalytic ozonation of phenolic acids over a Mn-Ce-O catalyst. Appl. Catal. B Environ. 2009, 90, 268-277. [CrossRef]

29. Gomes, J.; Quinta-Ferreira, M.E.; Costa, R.; Quinta-Ferreira, R.M.; Martins, R.C. Parabens degradation using catalytic ozonation over volcanic rocks. Environ. Sci. Pollut. Res. 2018, 25, 7346-7357. [CrossRef] [PubMed] 
30. Shin, G.; Sobsey, M. Reduction of Norwalk Virus, Poliovirus 1, and Bacteriophage MS2 by Ozone Disinfection of Water. Appl. Environ. Microbiol. 2003, 69, 3975-3978. [CrossRef]

31. Schaar, H.; Sommer, R.; Schürhagl, R.; Yillia, P.; Kreuzinger, N. Microorganism inactivation by an ozonation step optimized for micropollutant removal from tertiary effluent. Water Sci. Technol. 2013, 68, 311. [CrossRef]

32. Zhang, Q.; Liu, B.; Liu, Y.; Cai, X.; Liu, X.; Dai, R. Removal and inactivation of virus by drinking water treatment in the presence of bromide or iodide. J. Water Chem. Technol. 2015, 37, 96-101. [CrossRef]

33. Gomes, J.F.; Leal, I.; Bednarczyk, K.; Gmurek, M.; Stelmachowski, M.; Zaleska-Medynska, A.; Quinta-Ferreira, M.E.; Costa, R.; Quinta-Ferreira, R.M.; Martins, R.C. Detoxification of parabens using UV-A enhanced by noble metals- $\mathrm{TiO}_{2}$ supported catalysts. J. Environ. Chem. Eng. 2017, 5, 3065-3074. [CrossRef]

34. Gomes, J.; Lopes, A.; Bednarczyk, K.; Gmurek, M.; Stelmachowski, M.; Zaleska-Medynska, A.; Quinta-Ferreira, M.; Costa, R.; Quinta-Ferreira, R.; Martins, R.; et al. Effect of Noble Metals (Ag, Pd, $\mathrm{Pt}$ ) Loading over the Efficiency of $\mathrm{TiO}_{2}$ during Photocatalytic Ozonation on the Toxicity of Parabens. ChemEngineering 2018, 2, 4. [CrossRef]

35. Giannakis, S.; Darakas, E.; Escalas-Cañellas, A.; Pulgarin, C. Solar disinfection modeling and post-irradiation response of Escherichia coli in wastewater. Chem. Eng. J. 2015, 281, 588-598. [CrossRef]

36. Rafique, A.; Jiang, S.C. Genetic diversity of human polyomavirus JCPyV in Southern California wastewater. J. Water Health 2008, 6, 533-538. [CrossRef] [PubMed]

37. Ryschkewitsch, C.; Jensen, P.; Hou, J.; Fahle, G.; Fischer, S.; Major, E.O. Comparison of PCR-southern hybridization and quantitative real-time PCR for the detection of JC and BK viral nucleotide sequences in urine and cerebrospinal fluid. J. Virol. Methods 2004, 121, 217-221. [CrossRef] [PubMed]

38. Da Silva, A.K.; Le Saux, J.C.; Parnaudeau, S.; Pommepuy, M.; Elimelech, M.; Le Guyader, F.S. Evaluation of removal of noroviruses during wastewater treatment, using real-time reverse transcription-PCR: Different behaviors of genogroups I and II. Appl. Environ. Microbiol. 2007, 73, 7891-7897. [CrossRef] [PubMed]

39. Svraka, S.; Duizer, E.; Vennema, H.; de Bruin, E.; van der Veer, B.; Dorresteijn, B.; Koopmans, M. Etiological role of viruses in outbreaks of acute gastroenteritis in The Netherlands from 1994 through 2005. J. Clin. Microbiol. 2007, 45, 1389-1394. [CrossRef]

40. Loisy, F.; Atmar, R.L.; Guillon, P.; Le Cann, P.; Pommepuy, M.; Le Guyader, F.S. Real-time RT-PCR for norovirus screening in shellfish. J. Virol. Methods 2005, 123, 1-7. [CrossRef]

41. Kageyama, T.; Shinohara, M.; Uchida, K.; Fukushi, S.; Hoshino, F.B.; Kojima, S.; Takai, R.; Oka, T.; Takeda, N.; Katayama, K. Coexistence of multiple genotypes, including newly identified genotypes, in outbreaks of gastroenteritis due to Norovirus in Japan. J. Clin. Microbiol. 2004, 42, 2988-2995. [CrossRef]

42. Costafreda, M.I.; Bosch, A.; Pintó, R.M. Development, evaluation, and standardization of a real-time TaqMan reverse transcription-PCR assay for quantification of hepatitis A virus in clinical and shellfish samples. Appl. Environ. Microbiol. 2006, 72, 3846-3855. [CrossRef]

43. Rolfe, K.J.; Curran, M.D.; Mangrolia, N.; Gelson, W.; Alexander, G.J.; L'estrange, M.; Vivek, R.; Tedder, R.; Ijaz, S. First case of genotype 4 human hepatitis E virus infection acquired in India. J. Clin. Virol. 2010, 48, 58-61. [CrossRef] [PubMed]

44. Domenjoud, B.; Tatari, C.; Esplugas, S.; Baig, S. Ozone-based processes applied to municipal secondary effluents. Ozone Sci. Eng. 2011, 33, 243-249. [CrossRef]

45. Hunt, N.; Mariñas, B. Kinetics of Escherichia coli inactivation with ozone. Water Res. 1997, 31, 1355-1362. [CrossRef]

46. Hunt, N.K.; Mariñas, B.J. Inactivation of Escherichia coli with ozone: Chemical and inactivation kinetics. Water Res. 1999, 33, 2633-2641. [CrossRef]

47. Bofill-Mas, S.; Girones, R. Role of the environment in the transmission of JC virus. J. Neurovirol. 2003, 91, 54-58. [CrossRef]

48. Comerlato, J.; Souza-Campos, F.; Souza-Arantes, T.; Roos-Kulmann, M.I.; Trindade-Oliveira, M.; Rosado-Spilki, F.; Guedes-Frazzon, A.P.; Roehe, P.M.; Franco, A.C. Distribution and genetic diversity of the human polyomaviruses JC and BK in surface water and sewage treatment plant during 2009 in Porto Alegre, Southern Brazil. Braz. J. Biol. 2017, 77, 459-468. [CrossRef] [PubMed]

49. Qiu, Y.; Lee, B.E.; Neumann, N.; Ashbolt, N.; Craik, S.; Maal-Bared, R.; Pang, X.L. Assessment of human virus removal during municipal wastewater treatment in Edmonton, Canada. J. Appl. Microbiol. 2015, 119, 1729-1739. [CrossRef] 
50. Albinana-Gimenez, N.; Clemente-Casares, P.; Bofill-Mas, S.; Hundesa, A.; Ribas, F.; Girones, R. Distribution of Human Polyoma-viruses, Adenoviruses, and Hepatitis E Virus in the Environment and in a Drinking-Water Treatment Plant. Environ. Sci. Technol. 2006, 40, 7416-7422. [CrossRef]

51. Hollender, J.; Zimmermann, S.; Koepke, S.; Krauss, M.; McArdell, C.; Ort, C.; Singer, H.; von Gunten, U.; Siegrist, H. Elimination of Organic Micropollutants in a Municipal Wastewater Treatment Plant Upgraded with a Full-Scale Post-Ozonation Followed by Sand Filtration. Environ. Sci. Technol. 2009, 43, 7862-7869. [CrossRef]

(c) 2019 by the authors. Licensee MDPI, Basel, Switzerland. This article is an open access article distributed under the terms and conditions of the Creative Commons Attribution (CC BY) license (http:/ / creativecommons.org/licenses/by/4.0/). 